\title{
Novel Antipsychotic Drugs Approved in 2015: Brexpiprazole, Cariprazine, Aripiprazole Lauroxil \\ Canan KUS*
}

Department of Pharmaceutical Chemistry, Faculty of Pharmacy, Ankara University, 06100 Ankara, Turkey

\begin{abstract}
Antipsychotic agents, highly benefit for the treatment of a range of psychiatric disorders and act by blocking dopamine receptors in the brain and interfering with dopaminergic transmission. Schizophrenia and mania which are psychosis are treated by antipsychotic drugs. These medicines are classified as typical or atypical antipsychotic drugs. The recently developed drugs which are named 'atypical antipsychotics' are useful in patients that do not respond to treatment with other typical antipsychotics. This review puts emphasis on the recent progress in therapeutically attractive piperazine derivatives being novel atypical antipsychotics that were apporved in 2015 . Differences in safety-tolerability, affected receptors, activity, side effects are displayed in this review.
\end{abstract}

Keywords: Antipsychotic; Brexpiprazole; Cariprazine; Aripiprazole lauroxil

\section{Introduction}

This review consists of novel antipsychotics that approved in 2015, brexpiprazole, cariprazine, and aripiprazole lauroxil. All of the compounds are piperazine derivatives, their affects, affected receptors, and adverse effects are just about same. Differences in safetytolerability, affected receptors, activity, side effects are displayed in this review (Table 1).

All antipsychotic medications in current clinical use act primarily on the dopamine system (most are $\mathrm{D}_{2}$ antagonists) and are only efficacious for positive symptoms with little efficacy for all eviating the negative or cognitive symptoms [1]. They act by blocking dopamine receptors in the brain and interfering with dopaminergic transmission and they are used to treat psychosis, including schizophrenia and mania [2].

Schizophrenia is a psychiatric disorder that affects approximately $0.4 \%$ of individuals in the adult population worldwide that significantly impedes on normal vocational and social functioning [3-5]. Evidence for this disorder was first reported in humans as deficits in prepulse inhibition (PPI=Percentage pre-pulse inhibition) of the startle response, which serves as an operational measure of sensorimotor gating [6,7].

Schizophrenia is characterized by a constellation of signs and symptoms. It is aheterogeneous clinical syndrome, with no single symptom being pathognmonic of the disorder. Despite it being almost 100 years since [8] seminal description of dementia prae-cox, effective management of all of the symptoms of schizophreni are mains elusive.

Neuroleptic treatment can cause numerous side effects, including the often irreversible movement disorder tardive dyskinesia except for aripiprazole (they are rare) [9]. Many of the therapeutic actions and side effects of antipsychotics can take days to weeks, and in some cases months, to develop [10]. Because of that, basic research has turned increasingly toward an investigation of the effects of chronic neuroleptic treatment on neuronal systems. In addition, most second-generation antipsychotics are antagonists of serotonin 5- $\mathrm{HT}_{2 \mathrm{~A}}$ receptors and $\alpha-1$ adrenoreceptors, and individual compounds have a variety of effects on other monoamine receptors, such as $5-\mathrm{HT}_{1 \mathrm{~A}}$ receptors. These broad target effects have the objective of either improving antipsychotic efficacy (with additional effects on affective symptoms or cognitive deficits) or mitigating adverse effects like, extrapyramidal symptoms (EPS) $[11,12]$
If the $\mathrm{D}_{2}$ intrinsic activity is too high, this can lead to lack of robust antipsychotic activity as well as pronounced adverse effects related to increased $\mathrm{D}_{2}$ receptor tonus, like, nausea, vomiting, and motor side effects, such as hyperkinesias and restlessness [13-15], where as $\mathrm{D}_{2}$ antagonist activity leads to an increased risk of EPS and increased prolactin secretion [16]. Akathisia (the movement disorder) is another common side effect associated with dopamine receptor antagonists, and may be associated with subjective distress in patients [17].

\section{Classification of Antipsychotics}

Antipsychotics are classified both typical/atypical and first/second generation. Atypical antipsychotics are the recently developed drugs that are useful in patients that do not respond to treatment with other typical antipsychotics. Atypical antipsychotics have a pharmacological profile different from typical antipsychotic drugs that being primer generation. They cause less extrapyramidal side effects compared to the older typical antipsychotic drugs. Atypicals are more effective in treatment-resistant patients and have a greater efficacy to treat negative symptoms than typical antipsychotics [18].

Atypical antipsychotics are called as second generation and they act on many receptor types including dopamine and serotonin, by the way, they are more selective for dopamine receptors [19].

Atypical second generation antipsychotics (SGAs) appear to have broadly similar efficacy as FGAs against the manic symptoms of bipolar disorder, but there are important differences in their tolerability profiles, which are likely to be of particular relevance during long-term treatment [20]. Almost all have received regulatory approval for use in mania, including aripiprazole [21].

\section{Approved Antipsychotics in 2015}

Brexpiprazole, cariprazine, aripiprazole lauroxil are novel atypical antipsychotics. Aripiprazole, approved by the United States Food and

*Corresponding author: Canan KUS, Pharmaceutical Chemistry Department Faculty of Pharmacy, Ankara University, 06100 Tandogan Ankara, Turkey, Tel: +903122033075; Fax: +903122131081; E-mail: kus@pharmacy.ankara.edu.tr

Received June 14, 2016; Accepted June 22, 2016; Published June 27, 2016

Citation: Canan KUS (2016) Novel Antipsychotic Drugs Approved in 2015: Brexpiprazole, Cariprazine, Aripiprazole Lauroxil. Med chem (Los Angeles) 6: 425428. doi:10.4172/2161-0444.1000380

Copyright: (c) 2016 Canan KUS. This is an open-access article distributed under the terms of the Creative Commons Attribution License, which permits unrestricted use, distribution, and reproduction in any medium, provided the original author and source are credited. 


\begin{tabular}{|c|c|c|c|}
\hline Antipsychotic Agent & Brexpiprazole & Cariprazine & Aripiprazole lauroxil \\
\hline Generic name & Rexulty ${ }^{\circledR}$ & Vrayla® & Aristada $®$ \\
\hline Date of approval & 2015 July & 2015 September & 2015 October \\
\hline Chemical Structure & phenyl piperazine & phenyl piperazine & phenyl piperazine \\
\hline Classification & atypical antipsychotic, Second generation & $\begin{array}{l}\text { atypical antipsychotic, Second } \\
\text { generation }\end{array}$ & atypical antipsychotic, Second generation \\
\hline Affected receptor & $\begin{array}{l}\text { Serotonin-dopamine activity modulator, partial agonist } \\
\text { at } 5-\mathrm{HT}_{1 \mathrm{~A}} \text { and dopamine } \mathrm{D}_{2} \text { receptors, and antagonist at } \\
5-\mathrm{HT}_{2 \mathrm{~A}} \text { and noradrenaline } \alpha_{1 \mathrm{~B}} \text { and } \alpha_{2 \mathrm{C}} \text { receptors, all at } \\
\text { similar potency }\end{array}$ & $\begin{array}{l}\text { Dopamine } D_{2} \text { parcial agonist } \\
\text { agonism at } 5-H T_{1 A} \\
D_{3} \text {-preferring } \quad D_{3} / D_{2} \text {-receptor partial } \\
\text { agonist }\end{array}$ & $\begin{array}{l}\text { Dopamine } \mathrm{D}_{3} / \mathrm{D}_{2} \text { parcial agonist } \\
\text { Parcial agonism at } 5-\mathrm{HT}_{1 \mathrm{~A}} \\
\text { and } 5-\mathrm{HT}_{2 \mathrm{c}}\end{array}$ \\
\hline Usage for & Schizophrenia, major depressive disorder & Schizophrenia, bipolar disorder & $\begin{array}{l}\text { Acute schizophrenia bipolar disorder } \\
\text { schizophrenia, bipolar disorder }\end{array}$ \\
\hline Adverse effects & $\begin{array}{l}\text { Akathisia, } \\
\text { gastrointestinal side effects, } \\
\text { moderate weight gain, } \\
\text { increases in serum CPK } \\
\text { agitation, distress restlessness } \\
\text { weight gain, agitation, distress, and restlessness } \\
\text { Tardive Dyskinesia } \\
\text { Leukopenia, Neutropenia, and Agranulocytosis }\end{array}$ & $\begin{array}{l}\text { neuroleptic malignant syndrome } \\
\text { tardive dyskinesia } \\
\text { Sleepiness } \\
\text { high blood sugar } \\
\text { diabetes } \\
\text { Uncontrolled movements of the face } \\
\text { and body } \\
\text { Stiff muscles } \\
\text { Indigestion } \\
\text { Vomiting } \\
\text { Restlessness }\end{array}$ & $\begin{array}{l}\text { Akathisia } \\
\text { weight gain, } \\
\text { sleepiness, } \\
\text { drooling and tremors } \\
\text { headache, } \\
\text { agitation or anxiety, insomnia, } \\
\text { constipation, lightheadedness } \\
\text { hypersexuality } \\
\text { binge eating } \\
\text { compulsive shopping }\end{array}$ \\
\hline Recommended oral dose & $\begin{array}{l}\text { 2-4 mg/day in schizophrenia, } 2-3 \mathrm{mg} / \mathrm{day} \text { in major } \\
\text { depression }\end{array}$ & $\begin{array}{l}\text { an oral capsule available in } 4 \text { dosage } \\
\text { strengths: } 1.5 \mathrm{mg}, 3 \mathrm{mg}, 4.5 \mathrm{mg} \text {, and } \\
6 \mathrm{mg} .\end{array}$ & $\begin{array}{l}\text { every four to six weeks } \\
\text { every } 6 \text { weeks for the } 882 \mathrm{mg} \text { dose } \\
\text { as an injection }\end{array}$ \\
\hline
\end{tabular}

Table 1: Novel antipsychotics.

Drug Administration in 2002, appears to have fewer metabolic adverse effects than other atypical antipsychotics [22], by the way, aripiprazole lauroxil is approved in 2015. So far, aripiprazole is the only one $\mathrm{D}_{2}$ partial agonist, with moderate $\mathrm{D}_{2}$ intrinsic activity, has reached the market [23], whereas other compounds with higher $\mathrm{D}_{2}$ intrinsic activity are in development [24] or have been discontinued during development, often because of lack of sufficient clinical efficacy, like, bifeprunox [13].

Brexpiprazole is a novel serotonin dopamine activity modulator. It combines $5-\mathrm{HT}_{1 \mathrm{~A}}$ receptor partial agonism and low-intrinsic activity $\mathrm{D}_{2}$ receptor partial agonism with antagonist activity on a variety of 5-HT and a-adrenergic receptors. The main focus of this article is the receptors that are most influenced by brexpiprazole at clinically and pharmacologically relevant plasma exposures. The pharmacological effects of brexpiprazole in test models of positive symptoms of schizophrenia and of cognitive impairment $[25,26]$.

For brexpiprazole, the most common treatment-emergent adverse events were headache, insomnia and agitation; incidences of akathisia were lower in the brexpiprazole treatment groups (4.2\%-6.5\%) versus placebo $(7.1 \%)$. There were no clinically relevant changes in laboratory parameters and vital signs. Brexpiprazole $4 \mathrm{mg}$ is an efficacious and well-tolerated treatment for acute schizophrenia in adults [27].

For Cariprazine, the most commonly encountered adverse events in the mania trials were extrapyramidal disorder, akathisia, insomnia, vomiting, restlessness, sedation, vision blurred, and akathisia, extrapyramidal disorder, tremor, dyspepsia, vomiting, dizziness, diarrhea, and somnolence.

Cariprazine is a dopamine $\mathrm{D}_{3}$-preferring $\mathrm{D}_{3} / \mathrm{D}_{2}$ receptor partial agonist in late-stage clinical development for the treatment of schizophrenia, as well as for bipolar disorder (manic/mixed and depressive episodes), and as an adjunctive agent for the treatment of major depressive disorder [28].

Cariprazine differs from aripiprazole in terms of dopamine $\mathrm{D}_{3}$ receptor selectivity. In short-term, randomized controlled trials, cariprazine does not appear to adversely impact metabolic variables, prolactin, or the electrocardiogram (ECG) QT interval. In the fixeddose study of cariprazine that tested $1.5,3.0$, and $4.5 \mathrm{mg} /$ day, the most commonly encountered adverse events were insomnia, extrapyramidal disorder, sedation, akathisia, nausea, dizziness, vomiting, anxiety, and constipation. However, the differences in incidence versus placebo for these events were generally small [28].

Although aripiprazole has offered a new approach to stabilizing the dopaminergic system, an improvement could potentially be made by developing a novel compound that maintains significant partial agonist activity at $\mathrm{D}_{2}$ receptors, but with lower intrinsic activity. In addition to the issue of optimal $\mathrm{D}_{2}$ intrinsic activity, optimization of the pharmacological profile by a combination of additional target effects is a well known strategy to improve the clinical efficacy and tolerability of antipsychotics.

Aripiprazole monohydrate (AM) and aripiprazole lauroxil (AL) are two different long-acting injectable formulations of aripiprazole. AL is a prodrug of aripiprazole and available in $441 \mathrm{mg}, 662 \mathrm{mg}$ or $882 \mathrm{mg}$ strengths, also led to approval of dosing intervals of every 6 weeks for the $882 \mathrm{mg}$ dose [24].

Side effects of aristada (aripiprazole lauroxil): Akathisia, contraindication Cerebrovascular Adverse Reactions(IncludingStroke), Neuroleptik Malignant Syndrome, Tardive Dyskinesia, metabolic changes, hyperglycemia / diabetes mellitus, dyslipidemia, weight gain, orthostatic hypotension, leukopenia, neutropenia, agranulocytosis, seizures, potential for Cognitive and Motor Impairment, difficulties with body temperature regulation, dysphagia, Injection-Site Reactions (rash, swelling, redness, irritation at the point of injection), distonia and pregnancy and nursing complications [29].

Fountoulakis and Vieta published that aripiprazole appears effective for the treatment and prophylaxis against mania. The data on bipolar depression are so far negative; however there is a need for further study at lower dosages. The most frequent adverse effects are extrapyramidal signs and symptoms, especially akathisia, without any significant weight gain, hyperprolactinaemia or laboratory test changes [30]. 
On October 5, the U.S. Food and Drug Administration approved Aristada extended release injection to treat adults with schizophrenia. Aristada is administered by a health care professional every four to six weeks using an injection in the arm or buttocks. The efficacy of Aristada was demonstrated in part by a 12 -week clinical trial in 622 participants. In participants with acute schizophrenia who had been stabilized with oral aripiprazole, Aristada was found to maintain the treatment effect compared to a placebo.

Aristada and other atypical antipsychotic drugs used to treat schizophrenia have a Boxed Warning alerting health care professionals about an increased risk of death associated with the off-label use of these drugs to treat behavioral problems in older people with dementiarelated psychosis. No drug in this class is approved to treat patients with dementia-related psychosis. Aristada must be dispensed with a patient Medication Guide that describes important information about the drug's uses and risks [31].

\section{Atypical Antipsychotics and Related Receptors}

Most atypical antipsychotics more fully block dopamine receptors in the brain, while aripiprazole only partially blocks the activity of these receptors.

The role of serotonin in depression has also been well documented, and the affinity of atypical antipsychotics for the serotonin transporter as well as post-synaptic serotonin receptors suggests a role for this neurotransmitter [32]. Brexpiprazole has potent activity at the serotonin $5 \mathrm{HT}_{1 \mathrm{~A}}$ (partial agonist) and noradrenergic alpha-1 and alpha-2 (antagonist) receptors [33]. It exhibits moderate antagonist activity at the serotonin $5 \mathrm{HT}_{7}$ and $5 \mathrm{HT}_{2 \mathrm{C}}$ and histamine $\mathrm{H}_{1}$ receptors and negligible activity at the muscarinic cholinergic $\mathrm{M}_{1}$ receptor.

Brexpiprazole displayed almost equal subnanomolar affinities for several cloned human receptors, including $\mathrm{h} 5-\mathrm{HT}_{1 \mathrm{~A}}, \mathrm{hD}_{2 \mathrm{~L}}$, and $5-\mathrm{hHT}_{2 \mathrm{~A}}$ receptors, as well as ha1B- and ha2C-adrenoceptors. Although both brexpiprazole and aripiprazole showed high affinities for $\mathrm{h}-5 \mathrm{HT}_{1 \mathrm{~A}}$ and $\mathrm{hD}$, receptors, brexpiprazole had a slightly higher affinity for h5$\mathrm{HT}_{1 \mathrm{~A}}$ receptors than $\mathrm{hD}_{2}$ receptors, whereas the reverse was true for aripiprazole. Furthermore, brexpiprazole bound with about ten times higher affinity to $\mathrm{h} 5-\mathrm{HT}_{1 \mathrm{~A}}$ and $\mathrm{h} 5-\mathrm{HT}_{2 \mathrm{~A}}$ receptors and much higher affinity to ha1B- and ha2C-adrenoceptors than aripiprazole. The consequences of the high affinities of brexpiprazole for (and antagonist effects on) a 1B- and $a 2 \mathrm{C}$-adrenoceptors are more difficult to predict because of a lack of selective compounds for studying the functional importance of these receptors [26].

Cariprazine is one such orally active, putative antipsychotic which is described as a dopamine $\mathrm{D}_{3}$ receptor preferring $\mathrm{D}_{3} / \mathrm{D}_{2}$ receptor partial agonist [34,35].

Although both brexpiprazole and aripiprazole showed high affinities for $\mathrm{h}-5 \mathrm{HT}_{1 \mathrm{~A}}$ and $\mathrm{hD}_{2}$ receptors, brexpiprazole had a slightly higher affinity for h5- $\mathrm{HT}_{1 \mathrm{~A}}$ receptors than $\mathrm{hD}_{2}$ receptors, whereas the reverse was true for aripiprazole [25,26].

In particular, based on a lower intrinsic activity at $\mathrm{D}_{2}$ receptors and higher binding affinities for $5-\mathrm{HT}_{1 \mathrm{~A} / 2 \mathrm{~A}}$ receptors than aripiprazole, brexpiprazole would have a favorable antipsychotic potential without $\mathrm{D}_{2}$ receptor agonist and antagonist-related adverse effects. Brexpiprazole is a serotonin-dopamine activity modulator with a unique pharmacology, which may offer novel treatment options across a broad spectrum of central nervous system disorders [25].

Cariprazine has more moderate affinity for human $5-\mathrm{HT}_{1 \mathrm{~A}}$ receptors $(\mathrm{Ki} 3 \mathrm{nM})$ and acts as a partial agonist at this receptor. Affinity at other receptors is weaker. This includes human $5-\mathrm{HT}_{2 \mathrm{~A}}(\mathrm{Ki} 19 \mathrm{nM})$, histamine $\mathrm{H}_{1}(\mathrm{Ki} 23 \mathrm{nM}), 5-\mathrm{HT}_{7}(111 \mathrm{nM})$, and $5-\mathrm{HT}_{2 \mathrm{C}}(134 \mathrm{nM})$ receptors. Low affinity was observed for all tested adrenergic receptors [20].

There is a lack of understanding of the pharmacological mode of action of most psychoactive drugs. Many have similar 3D structures so that it is not easy to rationalize their differing relative potency in different clinical settings. However, significantly SAR for different degrees of internal mobility suggests that molecular dynamics should be an additional factor considered when trying to understand the mode of action of this clinically important family of molecules [36].

\section{Results}

All of the novel antipsychotics (brexpiprazole, cariprazine, aripiprazole lauroxil) are pheylpiperazine derivatives. At the same time, they are partial agonist at the dopamine $\mathrm{D}_{2}$ receptor.

It is apparent that the molecules, pathways, and systems thought to be involved in anxiety and depression are interconnected. The pharmacological profiles of psychoactive drugs are complex and, since they interact with many receptor sites, they often result in numerous side effects. Because of the side effects, more selective antipsychotic are needed.

\section{References}

1. Miyamoto S, Duncan GE, Marx CE, Lieberman JA (2005) Treatments for schizophrenia: a critical review of pharmacology and mechanisms of action of antipsychotic drugs. Mol Psychiatry 10: 79-104.

2. Lewinsohn PM, Klein DN, Seeley JR (1995) Bipolar Disorders in a Community Sample of Older Adolescents: Prevalence, Phenomenology, Comorbidity, and Course. J American Acad Child and Adoles Psychiatry 34: 454-463.

3. Mueser KT, McGurk SR (2004) Schizophrenia. Lancet 363: 2063-2072.

4. Saha S, Chant D, Welham J, McGrath J (2005) A systematic review of the prevalence of schizophrenia. PLoS Med 2: e141.

5. van Os J, Kapur S (2009) Schizophrenia. Lancet 374: 635-645.

6. Braff DL, Grillon C, Geyer MA (1992) Gating and habituation of the startle reflex in schizophrenic patients. Arch Gen Psychiatry 49: 206-215.

7. Oranje B, Gispen-de Wied CC, Verbaten MN, Kahn RS (2002) Modulating sensory gating in healthy volunteers: the effects of ketamine and haloperidol. Biol Psychiatry 52: 887-895.

8. Kraepelin E (1919) Dementia Praecox and Paraphrenia. Translation by Barclay RM. Livingstone, Edinburgh.

9. Steen VM, Løvlie R, MacEwan T, McCreadie RG (1997) Dopamine D3-receptor gene variant and susceptibility to tardive dyskinesia in schizophrenic patients. Mol Psychiatry 2: 139-145.

10. Beckmann B, Hippius H, Rüther E (1979) Treatment of schizophrenia. Prog Neuropsychopharmacol 3: 47-52.

11. Arnt J, Skarsfeldt T (1998) Do novel antipsychotics have similar pharmacological characteristics? A review of the evidence. Neuropsychopharmacology 18: 63101.

12. Meltzer HY (1999) The role of serotonin in antipsychotic drug action Neuropsychopharmacology 21: 106S-115S.

13. Newman-Tancredi A, Cussac D, Depoortere R (2007) Neuropharmacologica profile of bifeprunox: merits and limitations in comparison with other thirdgeneration antipsychotics. Curr Opin Investig Drugs 8: 539-554

14. Casey DE, Sands EE, Heisterberg J, Yang HM (2008) Efficacy and safety of bifeprunox in patients with an acute exacerbation of schizophrenia: results from a randomized, double-blind, placebo-controlled, multicenter, dose-finding study. Psychopharmacology (Berl) 200: 317-331.

15. Stip E, Tourjman $\vee(2010)$ Aripiprazole in schizophrenia and schizoaffective disorder: A review. Clin Ther 32 Suppl 1: S3-20.

16. Casey DE (1996) Side effect profiles of new antipsychotic agents. J Clin Psychiatry 57 Suppl 11: 40-45. 
17. Kane A, Hutchison WD, Hodaie M, Lozano AM, Dostrovsky JO (2009) Dopamine-dependent high-frequency oscillatory activity in thalamus and subthalamic nucleus of patients with Parkinson's disease. Neuroreport 20: 1549-1553.

18. Kane JM, Correll CU (2010) Past and present progress in the pharmacologic treatment of schizophrenia. J Clin Psychiatry 71: 1115-1124.

19. Correll CU (2010) From receptor pharmacology to improved outcomes: individualising the selection, dosing, and switching of antipsychotics. Eur Psychiatry Suppl 2: S12-21.

20. Kiss B, Horváth A, Némethy Z, Schmidt E, Laszlovszky I, et al. (2010) Cariprazine (RGH-188), a dopamine $D(3)$ receptor-preferring, $D(3) / D(2)$ dopamine receptor antagonist-partial agonist antipsychotic candidate: in vitro and neurochemical profile. J Pharmacol Exp Ther 333: 328-340.

21. García-Amador M, Pacchiarotti I, Valentí M, Sanchez RF, Goikolea JM, et al. (2006) Role of aripiprazole in treating mood disorders. Expert Rev Neurother 6: 1777-1783.

22. Makhzoumi ZH, McLean LP, Lee JH, Ibe Al (2008) Diabetic ketoacidosis associated with aripiprazole. Pharmacotherapy 28: 1198-1202.

23. Burris KD, Molski TF, Xu C, Ryan E, Tottori K, et al. (2002) Aripiprazole, a novel antipsychotic, is a high-affinity partial agonist at human dopamine D2 receptors. J Pharmacol Exp Ther 302: 381-389.

24. Ginovart N, Kapur S (2012) Role of Dopamine D2 Receptors for Antipsychotic Activity. Gross G and Geyer MA (eds.). Current Antipsychotics, Handbook of Experimental Pharmacology 212, Springer-Verlag Berlin Heidelberg.

25. Maeda K, Lerdrup L, Sugino H, Akazawa H, Amada N, et al. (2014) Brexpiprazole II: antipsychotic-like and pro-cognitive effects of a novel serotonin-dopamine activity modulator. J Pharmacol Exp Ther 350: 605-614.

26. Maeda K, Sugino H, Akazawa H, Amada N, Shimada J, et al. (2014) Brexpiprazole $\mathrm{I}$ : in vitro and in vivo characterization of a novel serotonindopamine activity modulator. J Pharmacol Exp Ther 350: 589-604.
27. Kane JM, Skuban A, Ouyang J, Hobart M, Pfister S, et al. (2015) A multicenter, randomized, double-blind, controlled phase 3 trial of fixed-dose brexpiprazole for the treatment of adults with acute schizophrenia. Schizophr Res 164: $127-$ 135.

28. Citrome $L$ (2013) New second-generation long-acting injectable antipsychotics for the treatment of schizophrenia. Expert Rev Neurother 13: 767-783.

29. Turncliff R, Hard M, Du Y, Risinger R, Ehrich EW (2014) Relative bioavailability and safety of aripiprazole lauroxil, a novel once-monthly, long-acting injectable atypical antipsychotic, following deltoid and gluteal administration in adult subjects with schizophrenia. Schizophr Res 159: 404-410.

30. Fountoulakis KN, Vieta E (2009) Efficacy and safety of aripiprazole in the treatment of bipolar disorder: a systematic review. Ann Gen Psychiatry 8: 16.

31. FDA approves new injectable drug to treat schizophrenia. U.S. Food and Drug Administration, news \& Events.

32. Krystal AD (2010) Antidepressant and Antipsychotic Drugs. Sleep Med Clin 5 571-589.

33. Bruijnzeel D, Tandon R (2016) Spotlight on brexpiprazole and its potential in the treatment of schizophrenia and as adjunctive therapy for the treatment of major depression. Drug Des Devel Ther 10: 1641-1647.

34. Agai-Csongor E, Domány G, Nógrádi K, Galambos J, Vágó I, et al. (2012) Discovery of cariprazine (RGH-188): a novel antipsychotic acting on dopamine D3/D2 receptors. Bioorg Med Chem Lett 22: 3437-3440.

35. Caccia S, Invernizzi RW, Nobili A, Pasina L (2013) A new generation of antipsychotics: pharmacology and clinical utility of cariprazine in schizophrenia. Ther Clin Risk Manag 9: 319-328.

36. Pan B, Lian J, Huang XF (2016) Aripiprazole Increases the PKA Signalling and Expression of the GABAA Receptor and CREB1 in the Nucleus Accumbens of Rats. J Mol Neurosci 59: 36-47. 